\title{
NMDA, AMPA, and Benzodiazepine Binding Site Changes in Alzheimer's Disease Visual Cortex
}

\author{
MARTHA D. CARLSON,* JOHN B. PENNEY, JR.*† AND ANNE B. YOUNG*1 \\ *Department of Neurology, University of Michigan, Ann Arbor, MI 48109 \\ †Department of Neurology, Massachusetts General Hospital and Harvard Medical School, Boston, MA 02114
}

Received 12 August 1992; Revised 15 January 1993; Accepted 29 January 1993

\begin{abstract}
CARLSON, M. D., J. B. PENNEY, JR. AND A. B. YOUNG. NMDA, AMPA, and benzodiazepine binding site changes in Alzheimer's disease visual cortex. NEUROBIOL AGING 14(4) 343-352, 1993.-Quantitative receptor autoradiography was used to measure the laminar distribution of $\left[{ }^{3} \mathrm{H}\right]$ glycine and $\left[{ }^{3} \mathrm{H}\right]$ glutamate binding to the $\mathrm{N}$-methyl-D-aspartate (NMDA) receptor complex, $\left[{ }^{3} \mathrm{H}\right] \mathrm{D}, \mathrm{L}-\alpha$-amino-3-hydroxy-5-methyl-4-isoxazolepropionic acid (AMPA) binding to the AMPA receptor, and [ $\left.{ }^{3} \mathrm{H}\right]$ flunitrazepam binding to the benzodiazepine (BDZ) receptor in three areas of visual cortex in control and Alzheimer's disease (AD) postmortem human brains (primary or striate visual cortex, visual association cortex, and higher-order visual association cortex, corresponding to Brodmann Areas 17, 18, and 21, respectively). In Area 17, binding to the NMDA, AMPA, and BDZ receptors was not significantly altered in the AD brains (except in layer VI for $\left[{ }^{3} \mathrm{H}\right]$ glycine and layer III for $\left[{ }^{3} \mathrm{H}\right]$ AMPA, where binding was reduced in the AD brains). Ligand binding to the two EAA receptors in Area 18 was, however, significantly reduced in the AD brains (layers I through III for $\left[{ }^{3} \mathrm{H}\right]$ glycine and layers III through VI for $\left[{ }^{3} \mathrm{H}\right] \mathrm{AMPA}$ ). In Area 21, binding to both the NMDA and BDZ receptors but not to the AMPA receptor, was significantly reduced in almost all laminae of the AD brains (layers I through VI for $\left[{ }^{3} \mathrm{H}\right]$ glycine and layers I through $\mathrm{V}$ for $\left[{ }^{3} \mathrm{H}\right]$ flunitrazepam). This hierarchical pattern of laminar binding loss with increasing complexity of association visual cortices is consistent with the increasing numbers of neurofibrillary tangles found in those areas, implicating NMDA and BDZ receptor bearing cells in AD neuropathology. AMPA receptor losses do not parallel the pathology, suggesting that AMPA receptors are not directly correlated with the pathology.
\end{abstract}

$\begin{array}{llccccc}\text { Glycine } & \text { NMDA } & \text { Benzodiazepine } & \text { Alzheimer's disease } & \text { Visual cortex } & \text { Occipital lobe } & \text { Temporal lobe } \\ \text { Area 17 } & \text { Area 18 } & \text { Area 21 } & & & \end{array}$

ALZHEIMER'S disease (AD), is marked by cortical dementia, memory loss, personality changes, and signs of cortical disconnection (2). The characteristic neuropathology of $\mathrm{AD}$ is the abundance of neurofibrillary tangles (NFT's) and amyloid-containing neuritic plaques (NP's) in the cerebral cortex and hippocampus (29). NFT's represent the accumulation of abnormal paired helical filaments in the cytoplasm of neurons, whereas NP's are comprised of dystrophic neurites and glial processes, with or without an amyloid core (68). In the cerebral cortex, NFT's are found primarily in pyramidal neurons and both NFT's and NP's are thought to be more common in association cortex than in the primary sensory regions (for reviews see $4,5,28,53,55,66$ ). In addition to the accumulation of NFT's, the large pyramidal cells of the cerebral cortex become significantly depleted in $\operatorname{AD}(36,67)$.

In a study by Lewis et al (34), the regional and laminar distribution of NFT's were found to be strikingly similar to the known distribution of corticocortical pyramidal neurons in the visual cortex of AD brains, whereas NP's had a less specific regional and laminar distribution $(4,5)$. Pyramidal neurons (found mainly in layers III and V) furnish the long corticocortical projections re- quired for the intricate connections between appropriate areas of cerebral cortex. It is thought that the dementia of $\mathrm{AD}$ results from the degeneration of these long corticocortical projection neurons and the loss of the connections they furnish (49). It was also determined in the study of Lewis et al. (34) that the number of NFT's was very low in primary striate cortex (primary visual, Area 17 but increased 20 -fold in the immediately adjacent visual association cortex (secondary visual, Area 18), and showed a further doubling in the next higher-order visual association cortex (tertiary visual, Areas 19, 20, 21). Thus, the number of NFT's progressively increased across primary, association, and higherorder association visual cortex in a manner which parallels their position in the proposed hierarchical organization of the visual cortex $(70,71)$. This hierarchical pattern of increasing NFT vulnerability within successive areas of the cerebral cortices appears to be correlated with the hierarchies of corticocortical connections $(4,15)$.

Excitatory amino acids (EAA's) are thought to be the principal excitatory neurotransmitters of cortical neurons $(9,11,14,16,19$, $23,64,69)$. Abundant evidence from neurochemical, electrophys-

${ }^{1}$ To whom requests for reprints should be addressed. 
iological, immunocytochemical, and transport studies indicate that the pyramidal neurons comprising corticocortical association, corticofugal, and some intracortical projections utilize glutamate as their primary EAA neurotransmitter (for a review see ref. 69). In addition, the EAA receptors of some of these cortical pathways have been characterized $(1,23,26,44,58,69)$.

Recent interest has focused on the potential role of EAA's in $\mathrm{AD}$ and the pathologic role of EAA's as excitotoxins has received a tremendous amount of attention (for reviews see refs. $10,17,23,31,38,39,40,51)$. Several studies have shown that excitotoxins can induce the formation of abnormal cytoskeletal proteins, paired helical filaments (NFT's), and NP's resembling those seen in AD brains $(3,12,31,39,40)$. NFT's have been found in glutamate-immunoreactive neurons (32)

The NMDA subtype of EAA receptor, by nature of its effects on calcium and its propensity to cause neurotoxicity, has been hypothesized to play a role in the neurodegeneration of $\mathrm{AD}(7$, $23,24,31,39,40,45,54)$. Furthermore, the glycine modulatory site of the NMDA receptor has been proposed as an attractive target for potential therapeutic regulation of EAA neurotransmission in $\mathrm{AD}$ $(8,57,58,59)$. Glutamatergic denervation and possible abnormal metabolism in $\mathrm{AD}$ has recently been shown (56). Selective reductions in EAA receptor levels in the cortex and hippocampus of $\mathrm{AD}$ also suggest a possible role for EAA neurotransmitters in the pathogenesis of the disease $(13,21,22,27,37,54,57,58,59)$.

In a recent study, specific laminar alterations in non-EAA receptors in $\mathrm{AD}$ cingulate cortex were found, suggesting that heterogeneities in cortical AD neuropathology are reflected in the laminar patterns of binding to postsynaptic receptors (72). Anatomical studies indicate that the characteristic pathology of $\mathrm{AD}$ distributes in relation to EAA cortical association pathways $(53,60)$. To further characterize the role of EAA's in the cortical pathways disrupted in $A D$, we examined the laminar distribution of $\left[{ }^{3} \mathrm{H}\right]$ glycine and $\left[{ }^{3} \mathrm{H}\right]$ glutamate binding to the NMDA receptor, $\left[{ }^{3} \mathrm{H}\right] \mathrm{AMPA}$ binding to the AMPA receptor, as well as $\left[{ }^{3} \mathrm{H}\right]$ flunitrazepam binding to the non-EAA benzodiazepine (BDZ) receptor using quantitative receptor autoradiography in three areas of visual cortex (primary, association, and higher-order association) in control and $\mathrm{AD}$ postmortem human brains.

\section{EXPERIMENTAL PROCEDURES}

\section{Tissue Preparation}

Brains of 8 individuals who had died with $A D$ and 8 nondemented controls were obtained at necropsy. $\mathrm{AD}$ pathology was defined according to previous neuropathologic criteria (29). The postmortem delay and age at death were matched so that the control and $\mathrm{AD}$ brains were not significantly different; the average postmortem delay was $16 \pm 4$ (SD) $h$ for the controls (range 12-24 $\mathrm{h}$ ) and $14 \pm 6 \mathrm{~h}$ for the AD cases (range $7-22 \mathrm{~h}$ ). The average age at death was $72 \pm 6$ years for the controls (range 64-82 years) and $73 \pm 9$ years for the AD brains (range 61-82 years). The brains were sectioned in a coronal plane, cut into slabs, frozen in crushed dry ice, placed in sealed plastic bags, and stored at $-70^{\circ} \mathrm{C}$. For this study, the slabs were brought from $-70^{\circ}$ to $-20^{\circ} \mathrm{C}$ and blocks containing either occipital lobe containing the calcarine fissure, corresponding to primary and association visual cortex (Brodmann Areas 17 and 18), or posterior middle temporal gyrus, corresponding to higher-order visual association cortex (Brodmann Area 21), were cut by JBP and presented to the other investigators as coded samples. These blocks were coated with Lipshaw embedding matrix, placed in zip-lock plastic bags, and stored at $-70^{\circ} \mathrm{C}$ until the time of the experiment. All binding assays and data analyses were completed before the code was broken and the statistical comparisons made.
On the day prior to assay, the blocks of occipital and temporal cortex were brought from $-70^{\circ}$ to $-20^{\circ} \mathrm{C}$ by placement in a $-20^{\circ} \mathrm{C}$ freezer overnight, mounted on cryotome chucks, and serial sections ( 20 microns thick) cut on a Lipshaw cryostat. The sections were then thaw-mounted onto twice gelatin-coated slides and stored at $-20^{\circ} \mathrm{C}$. All assays were performed within 2 days of sectioning. Additional sections were cut for cresyl violet and thioflavine S staining (see below).

\section{Materials}

D,L- $\alpha$-amino-3-hydroxy-5-methyl-4-isoxazolepropionic acid (AMPA), strychnine $\mathrm{HCl}$, and 3-(2-carboxypiperazin-4-yl)propyl1-phosphonic acid (CPP) were obtained from Research Biochemicals Inc. (Natick, MA). $\left[{ }^{3} \mathrm{H}\right] \mathrm{Glycine}, \mathrm{L}-\left[{ }^{3} \mathrm{H}\right]$ glutamate, and $\left[{ }^{3} \mathrm{H}\right]$ flunitrazepem were purchased from Amersham (Arlington Heights, IL) specific activities of $19.1,45$, and $83 \mathrm{Ci} / \mathrm{mmol}$, respectively). $\left[{ }^{3} \mathrm{H}\right] \mathrm{AMPA}$ was obtained from NEN-Dupont (Boston, MA; specific activity $60 \mathrm{Ci} / \mathrm{mmol}$ ). Quisqualic acid was purchased from Cambridge Research Biochemicals (Valley Stream, NY). All other chemicals were purchased from Sigma (St. Louis, MO).

\section{$\left[{ }^{3}\right.$ H]Glycine Binding Assay}

The glycine modulatory site (strychnine-insensitive) of the NMDA-receptor complex was assayed using a modified version of the method used for rat brain by McDonald et al.(43). Briefly, sections were prewashed in $50 \mathrm{mM}$ Tris- $\mathrm{Cl}$ buffer $\left(\mathrm{pH} \mathrm{7.4)}\right.$ ) at $25^{\circ} \mathrm{C}$ for $30 \mathrm{~min}$ and then dried with cool air. The sections were then immersed in cytomailers containing $4^{\circ} \mathrm{C}$ Tris-Cl buffer, $100 \mathrm{nM}$ $\left[{ }^{3} \mathrm{H}\right]$ glycine (Amersham, S.A. $19.9 \mathrm{Ci} / \mathrm{mmol}$ ) and $1 \mathrm{mM}$ strychnine (chloride salt). Preliminary experiments determined that these prewash and buffer conditions were optimal for a high ratio of specific to nonspecific $\left[{ }^{3} \mathrm{H}\right]$ glycine binding in the human tissue. Nonspecific binding was determined in the presence of $1 \mathrm{mM}$ unlabelled glycine and represented less than $10 \%$ of total binding. After a 35-min incubation period at $4^{\circ} \mathrm{C}$ to allow binding to occur, the sections were rapidly rinsed four times with $4 \mathrm{ml}$ each of $4^{\circ} \mathrm{C}$ Tris- $\mathrm{Cl}$ buffer only. The sections were then dried under a stream of cool air (total rinse time was less than $10 \mathrm{~s}$ ). This rinse protocol was also determined to be optimal for specific $\left[{ }^{3} \mathrm{H}\right]$ glycine binding in the human brain tissue used for this study (laminated visual cortex). A similar method for assaying the strychnine-insensitive $\left[{ }^{3} \mathrm{H}\right]$ glycine binding site in human tissue autoradiographically has been reported $(26,27)$.

\section{Other Ligand Assays}

The NMDA site of the NMDA-receptor complex was assayed as NMDA-sensitive $\left[{ }^{3} \mathrm{H}\right]$ glutamate binding in the presence of saturating amounts of quisqualate and kainate using a modification of the protocols of Greenamyre et al. (20) and Penney et al. (54). Briefly, following a 30-min prewash at $4^{\circ} \mathrm{C}$, sections were incubated in cytomailers $\left(4^{\circ} \mathrm{C}\right)$ with $65 \mathrm{nM}\left[{ }^{3} \mathrm{H}\right]$ glutamate plus $2.5 \mathrm{mM}$ quisqualate and $1 \mathrm{mM}$ kainate in $50 \mathrm{mM}$ Tris-acetate buffer $(\mathrm{pH}$ 7.4). 3-(2-Carboxypiperazin-4-yl)propyl-1-phosphonic acid (CPP, $100 \mathrm{mM}$ ) was used to determine nonspecific binding. Sections were then rinsed four times with $4 \mathrm{ml}$ each of $4^{\circ} \mathrm{C}$ Tris-acetate buffer, followed by two rinses of $2 \mathrm{ml}$ each of $2.5 \%$ glutaraldehyde in acetone $\left(4^{\circ} \mathrm{C}\right)$ and drying.

D,L- $\alpha$-amino-3-hydroxy-5-methyl-4-isoxazolepropionic acid $\left(\left[{ }^{3} \mathrm{H}\right] \mathrm{AMPA}, 10 \mathrm{nM}\right)$ was used to assay binding to the AMPA receptor in $50 \mathrm{mM}$ Tris- $\mathrm{Cl}$ buffer containing $2.5 \mathrm{mM} \mathrm{CaCl}_{2}$ and 30 $\mathrm{mM} \mathrm{KSCN}$ ( $\mathrm{pH} 7.2$ ) essentially as described above for the NMDA receptor, using $1 \mathrm{mM} \mathrm{L-glutamate}$ to determine nonspe- 
cific binding $(46,50,74)$. All assays were run in triplicate for the totals and duplicate for the nonspecific binding.

$\left[{ }^{3} \mathrm{H}\right]$ Flunitrazepam $(10 \mathrm{nM})$ was used to measure binding to the BDZ (benzodiazepine) receptor $(54,73)$. Briefly, sections were washed in $50 \mathrm{mM}$ Tris-citrate buffer ( $\mathrm{pH} 7.0$ ) three times for $5 \mathrm{~min}$ each at $4^{\circ} \mathrm{C}$, dried under a stream of cool air and exposed to ligand buffer for $30 \mathrm{~min}$ at $4^{\circ} \mathrm{C}$. Following incubation the sections received one quick dip in buffer $\left(4^{\circ} \mathrm{C}\right)$ followed by two $5 \mathrm{~min}$ rinses in buffer and a quick dry under hot air. Clonazepam ( $2 \mathrm{mM})$ was used to determine nonspecific binding.

\section{Quantification of Receptor Binding}

Upon completion of the assays, the slides were cut and taped onto sheets, apposed to tritium sensitive film (Amersham Hyperfilm) in sealed cassettes along with known radioactive standards $\left({ }^{14} \mathrm{C}\right)$ and exposed for 10 days to 4 weeks at $-20^{\circ} \mathrm{C}$. The films were developed in Kodak D-19 and binding levels were quantitated in each of the cortical areas with computer assisted densitometry using the MCID system (Imaging Research, Inc., St. Catharines; Ontario). Using this system, optical density values were converted to $\mathrm{pmol} / \mathrm{mg}$ protein using a computer generated polynomial regression analysis which compared film densities produced by the tissue sections to those of the known radioactive standards (52). Cresyl violet-stained adjacent sections (see below) were used as templates to delineate the six layers of each cortical area; multiple readings were taken and averaged in each layer of the overlaid autoradiograph using a variable size cursor. Cortical layers were classified according to the cytoarchitectonic scheme of Horton and Hedley-Whyte (25). It was possible to delineate layers I from II, II from III, III from IV or IVb, IVb from IVc, IVc or IV from V, V from VI, and VI from subcortical white matter in the autoradiograms. Ligand binding in these layers was determined in three separate cortical areas: primary visual cortex (Brodmann Area 17), visual association cortex (Brodmann Area 18), and the higher-order visual association cortex (Brodmann Area 21). All data presented were analyzed densitometrically from the autoradiograms. The level of binding of each ligand in each layer of the three cortical areas of the control samples were compared to those in the AD samples using a student $t$ test (unpaired, $\alpha=0.05$ ).

\section{Histology}

Cresyl violet staining histochemistry was carried out as follows. Sections adjacent to those used for autoradiography were fixed over paraformaldehyde vapor for a minimum of $48 \mathrm{~h}$, stained with $0.5 \%$ cresyl violet, dehydrated in graded alcohols and xylene, and coverslips affixed with Permount (Fisher). Additional paraformaldehyde fixed sections were stained with $0.1 \%$ Thioflavine $S$ for $\beta$-amyloid protein. These sections were analyzed using a fluorescent microscope to count the number of NFTs and NPs (neuritic plaques) in the Alzheimer's sections. The number of NFTs and NPs in each layer of each area were compared by ANOVA with post hoc comparisons.

\section{RESULTS}

The number of senile plaques and neurofibrillary tangles in each layer of the different regions of the Alzheimer's brains are shown in Table 1 . There were significant differences $[p<0.0001$; two-way analysis of variance (ANOVA)] in the number of plaques in the different layers but not in the different areas. The number of plaques in layers 3 and 5 was higher than in the other layers $(p<$ 0.05 by Fischer PLSD). The number of tangles in layer 5 were significantly different in the different areas $(p<0.02$ by ANOVA) with the higher-order association cortices having more tangles.

The laminar pattern of NMDA, AMPA, and BDZ binding clearly distinguished primary striate visual cortex (Brodmann Area 17) from the surrounding visual association cortex (Brodmann Area 18) and higher-order visual cortex (Brodmann Area 21). As others have reported $(1,26)$ in Area 17 , layer IVb binding was very low due to tritium absorption by the white matter in the line of Gennari. This decrease in layer IV binding was much less evident in Areas 18 and 21. The other major difference between the ligands was in the higher synaptic density in layer IVc that is not present in Areas 18 and 21. The ligands differed greatly in their amount of binding to this layer. NMDA and glycine binding sites showed similar patterns of laminar densities whereas the patterns of these two binding sites were different from AMPA and BDZ binding by three-way ANOVA; AMPA and BDZ binding patterns were different also. The details of this binding and the differences between control and AD are given below.

\section{$\left[{ }^{3} H\right]$ Glycine Binding}

Glycine binding to the NMDA receptor complex was found heterogeneously distributed across all laminae of each area of visual cortex examined. In the primary visual cortex (Brodmann Area 17, Figs. 1 and 2A), glycine binding was highest in layer IVc, moderately high in layers II, III, and somewhat lower in layers I, IVb, V, and VI. In all six layers of the primary visual cortex, the $\left[{ }^{3} \mathrm{H}\right]$ glycine binding levels were slightly reduced in the $\mathrm{AD}$ brains; however, only in layer VI did the data reach statistical significance. In visual association cortex (Brodmann Area 18, Figs. 1 and 3A), glycine binding was highest in layers II and III, and lower in layers I, IV, V, and VI. In this area of visual cortex,

TABLE 1

NUMBER OF SENILE PLAQUES AND NEUROFIBRILLARY TANGLES PER $1 \mathrm{~mm}^{2}$ FIELD IN VISUAL CORTEX OF THE ALZHEIMER'S DISEASE BRAINS

\begin{tabular}{lccccccc}
\hline & \multicolumn{2}{c}{ Senile Plaques (Mean \pm SD) } & & \multicolumn{2}{c}{ Neurofibrillary Tangles (Mean \pm SD) } \\
\cline { 2 - 3 } \cline { 7 - 8 } & Area 17 & Area 18 & Area 21 & & Area 17 & Area 18 & Area 21 \\
\hline Layer 1 & $1.3 \pm 1.8$ & $1.8 \pm 1.5$ & $2.9 \pm 2.6$ & & $0.2 \pm 0.4$ & 0 & 0 \\
Layer 2 & $3.3 \pm 6.7$ & $3.8 \pm 2.6$ & $3.8 \pm 1.2$ & & $3.5 \pm 8.1$ & $4.7 \pm 5.2$ & $6.5 \pm 5.0$ \\
Layer 3 & $5.7 \pm 7.2$ & $9.2 \pm 5.7$ & $7.5 \pm 3.7$ & & $2.2 \pm 5.3$ & $5.8 \pm 12$. & $5.9 \pm 3.1$ \\
& & & & & 0 & 0 & \\
Layer 4 & $2.0 \pm 2.8$ & $1.7 \pm 1.8$ & $1.8 \pm 1.7$ & & 0 & $1.0 \pm 2.5$ & $0.4 \pm 0.5$ \\
Layer 5 & $4.0 \pm 3.2$ & $5.2 \pm 4.0$ & $5.6 \pm 2.0$ & & $6.0 \pm 7.9$ & $9.5 \pm 5.7 *$ \\
Layer 6 & $1.7 \pm 2.6$ & $3.0 \pm 2.7$ & $3.4 \pm 2.1$ & & $0.8 \pm 2.0$ & $2.7 \pm 3.0$ & $2.1 \pm 1.7$ \\
\hline
\end{tabular}

* Significantly greater than Area $17(p<0.05)$ by ANOVA with post-hoc Schéffé test. 


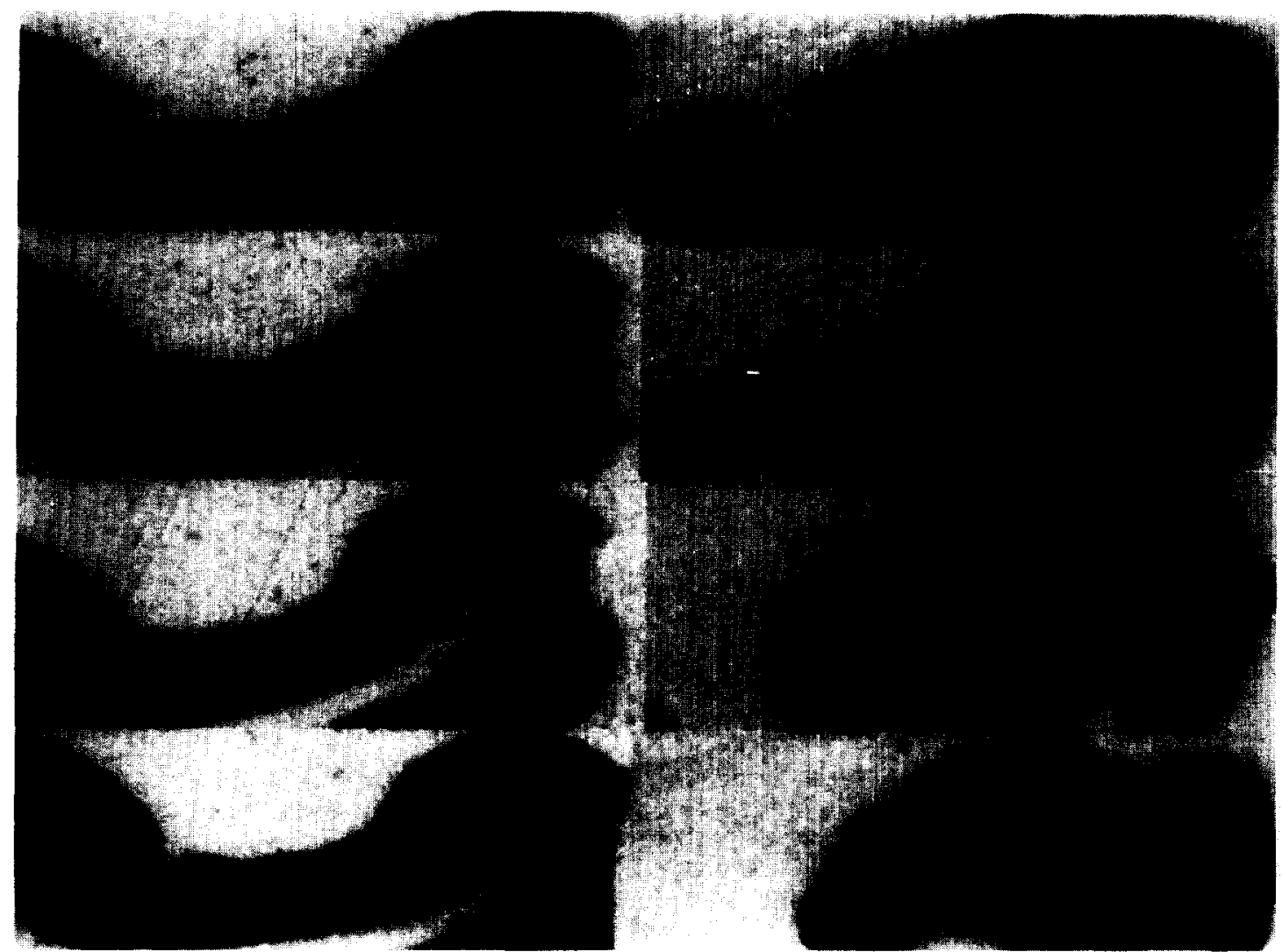

FIG. 1. Representative autoradiograms showing the binding of $100 \mathrm{nM}\left[{ }^{3} \mathrm{H}\right]$ glycine (top), $65 \mathrm{nM}\left[{ }^{3} \mathrm{H}\right]$ glutamate under NMDApreferring conditions (upper), $10 \mathrm{nM}\left[{ }^{3} \mathrm{H}\right] \mathrm{AMPA}$ (lower) and $\left.10 \mathrm{nM} \mathrm{[}{ }^{3} \mathrm{H}\right]$ flunitrazepam (bottom) to Areas 17 and 18 of nearly adjacent sections from a representative control (left) and $\mathrm{AD}$ (right) occiptal cortex. Layer IVc of Area 17 is easily distinguishable as a layer of dense binding in the $\left[{ }^{3} \mathrm{H}\right]$ glycine, $\left[{ }^{3} \mathrm{H}\right]$ glutamate, and $\left[{ }^{3} \mathrm{H}\right]$ flunitrazepam autoradiograms and as a layer of low binding (along with layer IVb) in the $\left[{ }^{3} \mathrm{H}\right] \mathrm{AMPA}$ autoradiograms.

glycine binding in layers I, II, and III was significantly reduced (approximately $30 \%$ ) in the $\mathrm{AD}$ brains, although binding in all layers was somewhat lower in the $\mathrm{AD}$ brains. In the higher-order visual association cortex (Brodmann Area 21, Figs. 4 and 5A), glycine binding was significantly reduced (approximately $30 \%$ ) in all laminae of the AD brains. Thus, there was an increasing reduction in glycine binding as one went from primary visual cortex to visual association cortex to higher-order association visual cortex.

\section{NMDA-Sensitive $\left[{ }^{3} H\right]$ Glutamate Binding}

The laminar pattern of NMDA-sensitive $\left[{ }^{3} \mathrm{H}\right]$ glutamate binding in the primary visual cortex was very similar to that found for $\left[{ }^{3} \mathrm{H}\right]$ glycine (i.e., highest binding was found in layer IVc, moderately high binding in layers II, III, and lower binding in layers I, $\mathrm{IVb}, \mathrm{V}$, and VI, Figs. 1 and 2B). In fact, in all three areas of visual cortex examined, $\left[{ }^{3} \mathrm{H}\right]$ glycine and $\left[{ }^{3} \mathrm{H}\right]$ glutamate showed parallel distributions in their laminar binding pattern, supporting the notion that the two ligands are simply binding to different sites on the same NMDA receptor complex. Other studies in postmortem human cortex have also demonstrated a high degree of congruence between the binding patterns of $\left[{ }^{3} \mathrm{H}\right]$ glycine and $\left[{ }^{3} \mathrm{H}\right]$ glutamate, consistent with the notion that these ligands bind to different regions of the same NMDA receptor complex (26). Furthermore, $\left[{ }^{3} \mathrm{H}\right]$ glutamate binding to the NMDA receptor complex in this study followed the same trend as glycine binding in the AD brains (i.e., the patterns of change of the two ligands were not signifi- cantly different by two-way ANOVA); that is, a progressive de crease in binding is seen in the AD brains in the visual association cortices, although the data did not reach statistical significance (Figs. 1, 2B, 3B, 4, and 5B).

\section{$\left.I^{3} H\right] A M P A$ Binding}

The laminar distribution of $\left[{ }^{3} \mathrm{H}\right]$ AMPA binding differed from that of the two NMDA receptor ligands. $\left[{ }^{3} \mathrm{H}\right]$ AMPA binding was highest in layers II and III of primary visual cortex and relatively low in layer IVc (Figs. 1 and $2 \mathrm{C}$ ). In layer II of primary visual cortex, $\left[{ }^{3} \mathrm{H}\right]$ AMPA binding was significantly reduced (approximately $35 \%$ ) in the AD brains, although binding in all laminae was slightly lower. In the visual association cortex (Figs. 1 and $3 \mathrm{C}$ ), $\left[{ }^{3} \mathrm{H}\right]$ AMPA binding remained highest in layers II and III but in the AD brains was significantly reduced in layers III, IV, V, and VI. In the higher-order visual association cortex, however, $\left[{ }^{3} \mathrm{H}\right] \mathrm{AMPA}$ binding was not significantly altered in any layer of the AD brains (Figs. 4 and $5 C$ ). Therefore, the laminar pattern of $\left[{ }^{3} \mathrm{H}\right]$ AMPA binding in the three areas of visual cortex studied differed from that of the NMDA receptor complex. This may reflect the different pattern of distribution or density of the two EAA receptor types in these cortical laminae.

\section{$\left[{ }^{3}\right.$ H]Flunitrazepam Binding}

$\left[{ }^{3} \mathrm{H}\right]$ Flunitrazepam binding to the benzodiazepine receptor gave a somewhat different pattern than that of the two EAA receptors 

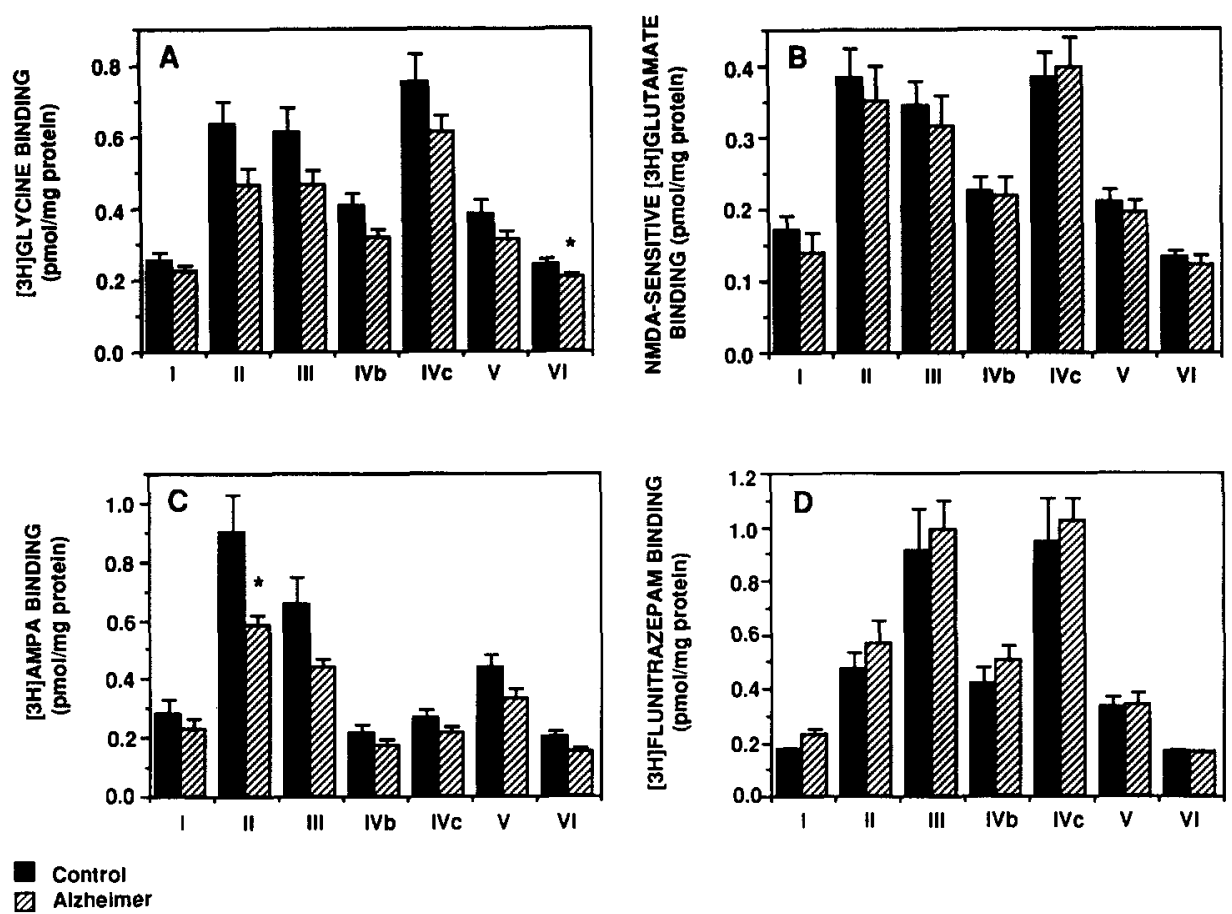

FIG. 2. Primary Visual Cortex: Area 17. Histograms of autoradiographic binding to primary visual (striate) cortex, Brodmann Area 17, for each ligand assayed. (A) $100 \mathrm{nM}\left[{ }^{3} \mathrm{H}\right]$ glycine binding; (B) NMDA-sensitive $65 \mathrm{nM}\left[{ }^{3} \mathrm{H}\right]$ glutamate binding; (C) $10 \mathrm{nM}\left[{ }^{3} \mathrm{H}\right] \mathrm{AMPA}$ binding; (D) $10 \mathrm{nM}\left[{ }^{3} \mathrm{H}\right]$ flunitrazepam binding. Error bars represent the SEM. ${ }^{*} p<0.05$ and ${ }^{* *} p<0.01$, in comparing Alzheimer's to control brains by unpaired student $t$ test.
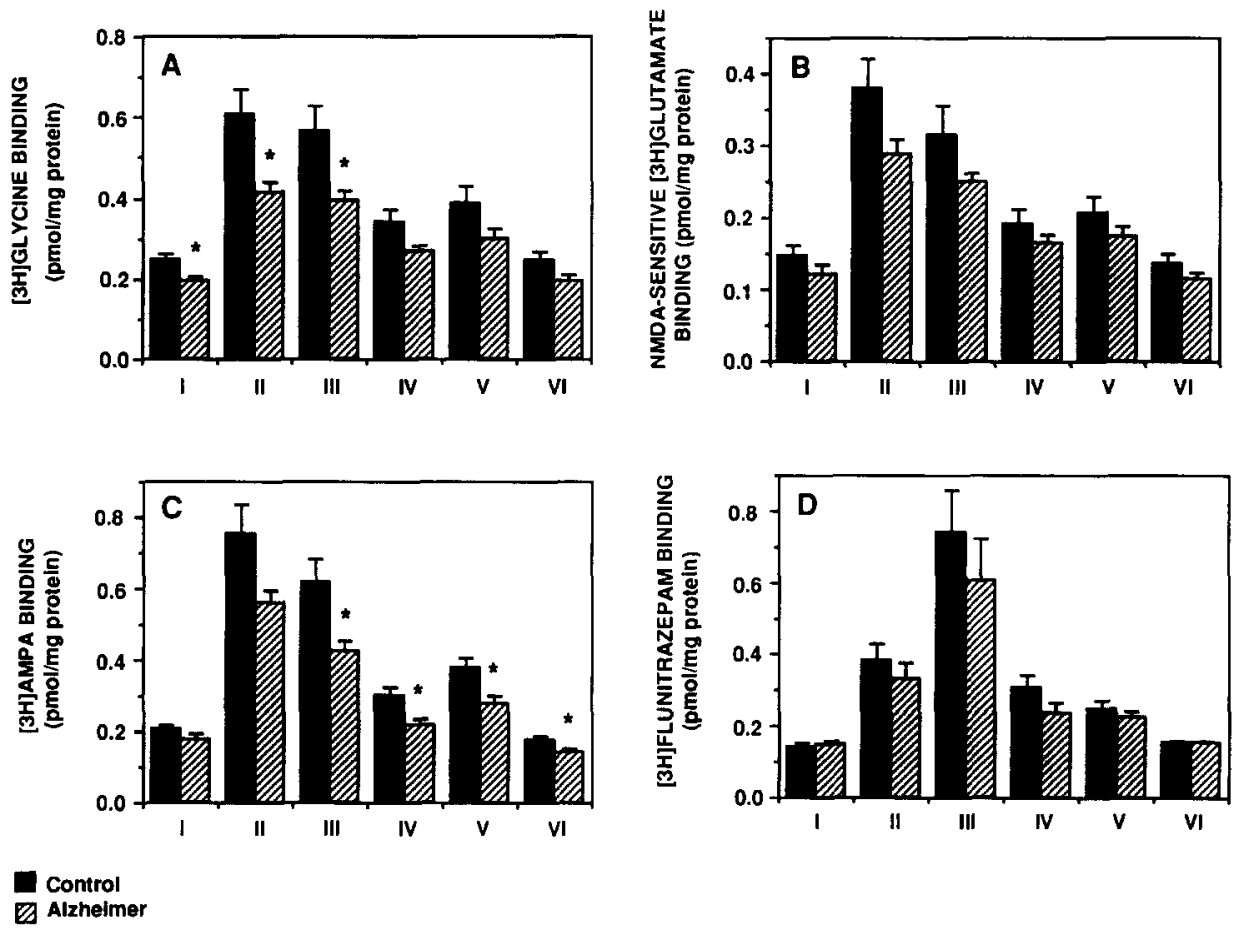

Alzheime

FIG. 3. Visual Association Cortex: Area 18. Histograms of autoradiographic binding to visual association cortex, Brodmann Area 18, for each ligand assayed. (A) $100 \mathrm{nM}\left[{ }^{3} \mathrm{H}\right]$ glycine binding; (B) NMDA-sensitive $65 \mathrm{nM}\left[{ }^{3} \mathrm{H}\right]$ glutamate binding; (C) $10 \mathrm{nM}\left[{ }^{3} \mathrm{H}\right]$ AMPA binding; (D) $10 \mathrm{nM}\left[{ }^{3} \mathrm{H}\right]$ flunitrazepam binding. Error bars represent the SEM. ${ }^{*} p<0.05$ and ${ }^{* *} p<0.01$, in comparing Alzheimer's to control brains by unpaired student $t$ test. 


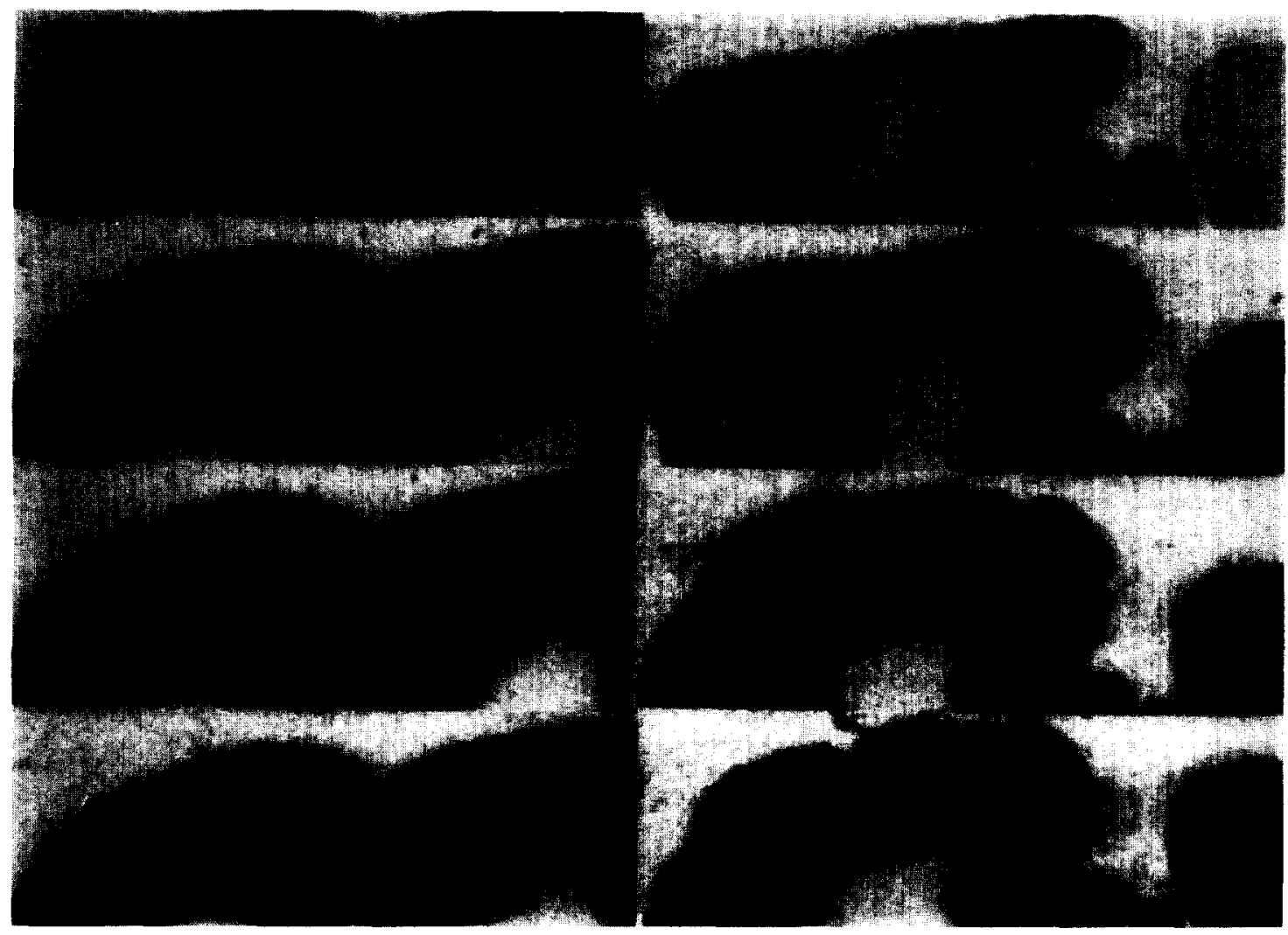

FIG. 4. Representative autoradiograms showing the binding of $100 \mathrm{nM}\left[{ }^{3} \mathrm{H}\right]$ glycine (top), $65 \mathrm{nM}\left[{ }^{3} \mathrm{H}\right]$ glutamate under NMDApreferring conditions (upper), $10 \mathrm{nM}\left[{ }^{3} \mathrm{H}\right] \mathrm{AMPA}$ (lower) and $10 \mathrm{nM}\left[{ }^{3} \mathrm{H}\right]$ flunitrazepam (bottom) to Area 21 of nearly adjacent sections from a representative control (left) and AD (right) posterior temporal lobe.

examined. In primary visual cortex, $\left[{ }^{3} \mathrm{H}\right]$ flunitrazepam binding was highest in layers III and IVc, with lower binding in layers I, II, IVb, V, and VI (Figs. 1 and 2D). In the association cortices, $\left[{ }^{3} \mathrm{H}\right]$ flunitrazepam binding remained highest in layer III (Figs. 1. $3 \mathrm{D}, 4$ and $5 \mathrm{D})$. In contrast to the EAA receptors, $\left[{ }^{3} \mathrm{H}\right]$ flunitrazepam binding had a nonsignificant trend of slightly higher in the AD brains in primary visual cortex. The binding of $\left[{ }^{3} \mathrm{H}\right]$ flunitrazepam in visual association cortex was only slightly reduced in the AD brains. In the higher-order visual association cortex, however, $\left[{ }^{3} \mathrm{H}\right]$ flunitrazepam binding was significantly reduced in layers I through $\mathrm{V}$ of the $\mathrm{AD}$ brains.

\section{DISCUSSION}

\section{Summary of Results and Comparison With Other Studies}

In this study, a hierarchical pattern of receptor binding vulnerability in $\mathrm{AD}$ was examined at successive levels of visual cortex. The hierarchical pattern was most obvious for $\left[{ }^{3} \mathrm{H}\right]$ glycine binding to the NMDA receptor, although a parallel trend was obtained for NMDA-sensitive $\left[{ }^{3} \mathrm{H}\right]$ glutamate binding, where increasing reductions in laminar binding were found at each higher level of association cortex. The pattern of glycine binding loss paralleled the increase in $\mathrm{AD}$ neuropathology (NFT number) seen in primary, association, and higher-order association visual cortex $(4,34)$. Binding to the AMPA receptor was reduced as well but only at the first level of visual association cortex (Brodmann Area 18), whereas the $\mathrm{BDZ}$ receptor binding pattern was reduced only in the highest-order level of visual association cortex (Brodmann Area 21).

The results obtained in our study for the laminar distribution of $\left[{ }^{3} \mathrm{H}\right]$ glycine and $\left[{ }^{3} \mathrm{H}\right]$ glutamate binding to the NMDA receptor, as well as $\left[{ }^{3} \mathrm{H}\right]$ AMPA binding to the AMPA receptor, in human primary visual cortex are very similar to those first obtained by Jansen et al. (26) and Albin et al. (1), although different cytoarchitectonic schemes were used in the two studies. The cytoarchitectonic scheme incorporated by Jansen et al. was developed for the macaque visual cortex (35) and includes both a layer IVa as well as a subdivision of layer IVc into IV ca and IVcb. Thus, differences between our studies and that of Jansen et al. (26) lie in the assignment of cortical laminae. In our studies, we used the cytoarchitectonic scheme of Horton and Hedley-Whyte (25), which was developed for the human striate visual cortex and which does not include a layer IVa or the subdivision of layer IVc into a and $b$. In addition, our study further examines EAA receptor binding parameters at higher levels of visual association cortex and compares the control data to that of AD brains. Binding to the $B D Z$ receptor was also included in our study, and our results were found to be comparable to those obtained by other groups for human primary visual cortex $(61,75)$. Thus, the laminar distributions of $\mathrm{EAA}$ and $\mathrm{BDZ}$ receptors are quite distinctive in the human visual cortex, suggesting that the pattern of EAA and non-EAA neurotransmission may vary from layer to layer in each area of the visual hierarchy. The results provided in our study contribute additional information about which types of EAA receptors in the visual hierarchy are selectively vulnerable in $\mathrm{AD}$.

\section{Visual Cortex, AD Neuropathology, and Excitatory Amino Acids}

The human visual system is a complicated array of networks interconnecting many levels of association cortices. Recent studies 

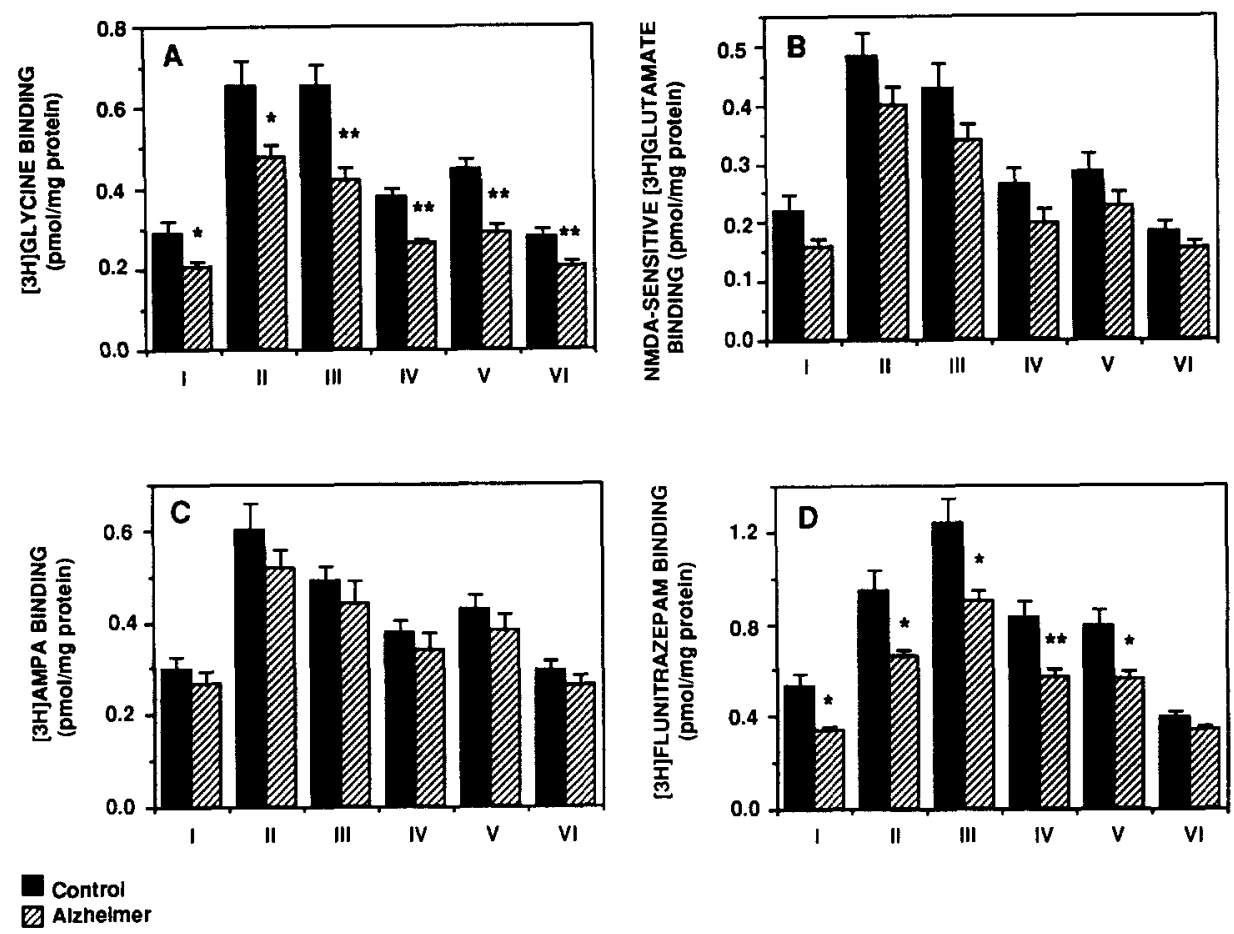

FIG. 5. Higher-Order Visual Association Cortex: Area 21. Histograms of autoradiographic binding to higher-order visual association cortex, Brodmann Area 21, for each ligand assayed. (A) $100 \mathrm{nM}\left[{ }^{3} \mathrm{H}\right]$ glycine bindng; (B) NMDA-sensitive $65 \mathrm{nM}\left[{ }^{3} \mathrm{H}\right]$ glutamate binding; (C) $10 \mathrm{nM}\left[{ }^{3} \mathrm{H}\right] \mathrm{AMPA}$ binding; (D) $10 \mathrm{nM}$ $\left[{ }^{3} \mathrm{H}\right]$ flunitrazepam binding. Error bars represent the SEM. ${ }^{*} p<0.05$ and ${ }^{* *} p<0.01$, in comparing Alzheimer's to control brains by unpaired student $t$ test.

propose the existence of an elaborate hierarchical processing stream to explain the various connections of the association cortices of the visual system $(15,41,70,71)$.

Interestingly, a similar hierarchical pattern of neuropathology has recently been discovered in $\mathrm{AD}$ visual cortex $(4,34)$. In these studies, NFT's found in pyramidal neurons increase in number at each step of the hierarchy from primary visual cortex to higher levels of visual association cortices. There appears to be a pattern of selective vulnerability in the neuropathological pattern of cortical neurodegeneration in $\mathrm{AD}$ visual cortex as evidenced with the increasing numbers of NFT's. The findings from these studies may provide an anatomical basis for the loss of intellectual functions in $\mathrm{AD}$ and are consistent with the hypothesis that the dementia in $\mathrm{AD}$ results from the loss of the structural and functional integrity of the long corticocortical projection systems $(34,49,53)$.

Abundant evidence exists for the role of EAA's in the visual cortex $(9,26,30,42,61)$. These studies indicate that the pyramidal neurons comprising corticocortical association fibers, such as those found in the visual cortex, utilize glutamate as their primary EAA neurotransmitter. Although many investigators have demonstrated selective EAA receptor changes in AD in both cortex (22, $23,57,58,59,62,72)$ and hippocampus $(13,21,23,27,37,54)$, the results presented here provide the first comprehensive study of EAA receptor alterations in $\mathrm{AD}$ visual cortex. It is not known, however, at what point in the course of the disease that these alterations in EAA receptors become manifest. This is an important issue, for the fact that EAA receptor levels change with $\mathrm{AD}$ may only be a result of the neurodegenerative process and thus simply an effect of the disease, rather than an active cause. In future studies, an examination of the expression of the genes and proteins for EAA and GABA receptors is warranted to ascertain whether there may be a fundamental alteration in these receptors that precedes the overt pathology. These latter studies would have to be carried out in early $\mathrm{AD}$ cases or even in normal aging to determine the relationship of gene and protein expression to the progression of the disease.

The laminar pattern of EAA and BDZ receptor binding within the primary and association visual cortices probably results in a heterogeneous character of EAA mediated neurotransmission within the laminar hierarchy of the visual cortex. Autoradiographic studies of neurotransmitter receptors can provide novel information about the anatomical and functional organization of the visual cortex and may provide insight into the AD neuropathology also seen in those same areas of visual cortex. Anatomical studies have indicated that the characteristic pathology of $A D$ is often associated with EAA cortical association pathways $(53,60)$. In our study, AMPA receptor losses do not parallel the pathology, suggesting that AMPA receptors do not play a direct role in the $\mathrm{AD}$ pathology. The significant alterations in glycine binding to the NMDA receptor complex observed in our study, however, are intriguing because NMDA receptors have been implicated in synaptic plasticity in the primary visual cortex $(5,18)$. In addition, it has been speculated that EAA receptors may play a role in the generation of $\mathrm{AD}$ neuropathology, by nature of their excitotoxic potential $(3,12,23,31,39,40,51,56)$. Thus, EAA receptor sites may be exploited therapeutically in the design of future treatment for $\mathrm{AD}$.

\section{Modulatory Role of Glycine}

In light of these interpretations, it is interesting that glycine, of the four ligands examined in our study, most directly reflected the hierarchical pattern of $\mathrm{AD}$ neuropathology. The changes in glycine binding were significant while those of NMDA were not. Note, 
however, that the addition of glycine to the incubation mixture enhances basal NMDA-sensitive glutamate binding (the so-called glycine-dependent NMDA receptor binding). We did not add glycine to the incubation media for the NMDA-sensitive glutamate binding assay. The addition of glycine to our glutamate assay may have resulted in a more significant decrease in NMDA receptor binding in the $\mathrm{AD}$ brains $(57,58,59)$. A decrease in glutamate binding to the NMDA receptor in AD may in fact represent a reduction in the glycine enhancement of glutamate binding (62). Clearly, these modulatory interactions require further study. Nevertheless, these findings are provocative because of glycine's proposed role as a neuro-modulator (45). It has been suggested that the glycine allosteric site of the NMDA receptor could be targeted therapeutically for the possible treatment of neurodegenerative disorders such as $\operatorname{AD}(8,23,24)$. In response to this suggestion, recent reports have focused on glycine and found that its modulation of the NMDA receptor is in fact disrupted in $\operatorname{AD}(57,58,59,62)$. With the recent cloning of a family of NMDA receptors, it will be important to determine whether discrete subtypes of NMDA receptors are differentially affected in $\operatorname{AD}(33,47,48)$. The discrete subtypes of the NMDAR2 genes and the various splice variants of the NMDARl gene have different sensitivities to glycine
$(33,47,65)$. Furthermore, recent in situ hybridization data would suggest that the different NMDAR2 genes and the different splice variants of the NMDARI gene have unique distributions in brain $(47,63)$. Perhaps cells that preferentially express one or the other of these subtypes are particularly vulnerable to the pathology of $\mathrm{AD}$. With the new antibodies that are becoming available to examine the localization of these subtypes and the in situ hybridization methods for determining their cellular localization, it should be able to address these possibilities in more detail. The previous studies $(57,58,59,62)$, combined with the results presented here, provide data to support a therapeutic role for glycinergic drugs in AD. It has been suggested that perhaps a partial glycine agonist, a drug which combines the glycine agonist properties to potentially enhance cognition with the glycine antagonist properties to retard disease progression, may actually provide the best solution (24).

\section{ACKNOWLEDGEMENTS}

We thank Bradley Hyman and Kristin Marzloff for assistance with the thioflavin stains and $\mathrm{H}$. Christopher Campbell for assistance in collection and preparation of human brain samples. Research was supported by USPHS Grant No. AG08671

\section{REFERENCES}

1. Albin, R. L.; Sakurai, S. Y.; Makowiec, R. L.; Higgins, D. S.; Young, A. B.; Penney, J. B. Excitatory amino acid and GABA binding sites in human striate cortex. Cerebral Cortex 1:499-509, 1991

2. Alzheimer, A. Uber eine eigenartige Erkankung der hirnrinde. Allg Z Psychiat Ihre Grenzgeh 64:146-148, 1907

3. Arendash, G. W.; Millard, W. J.; Dunn, A. J.; Meyer, E. M. Longterm neuropathological and neurochemical effects of nucleus basalis lesions in the rat. Science 238:952-956, 1987

4. Arnold, S. E.; Hyman, B. T.; Flory, J.; Damasio, A. R.; Van Hoesen, G. W. The topographical and neuroanatomical distribution of neurofibrillary tangles and neuritic plaques in the cerebral cortex of patients with Alzheimer's disease. Cerebral Cortex 1:103-116; 1991.

5. Arriagada, P. V.; Growdon, J. H.; Hedley-White, E. T.; Hyman, B. T. Neurofibrillary tangles but not senile plaques parallel duration and severity of Alzheimer's disease. Neurology 42:631-639; 1992.

6. Artola, A.; Singer, W. Long-term potentiation and NMDA receptors in rat visual cortex. Nature 330:649-652; 1987.

7. Bowen, D. M. Treatment of Alzheimer's disease - molecular pathology versus neurotransmitter based-therapy. Br. J. Psych. 157:327$330 ; 1990$.

8. Bowen, D. M.; Francis, P. T.; Lowe, S. L.; Pangalos, M. N.; Procter, A. W.; Steele, J. E. Pyramidal neuron loss and "glycine-site therapy": A need for an animal model and study of late-life depression. Neurobiol. Aging 10:616-618; 1989.

9. Baughman, R. W.; Gilbert, C. D. Aspartate and glutamate as possible neurotransmitters in the visual cortex. J. Neurosci. 1:427-439; 1981.

10. Choi, D. W. Glutamate neurotoxicity and diseases of the nervous system. Neuron 1:623-634; 1988.

11. Cotman, C. W.; Monaghan, D. T.; Ottersen, O. P.; Storm-Mathisen, $\mathrm{J}$. Anatomical organization of excitatory amino acid receptors and their pathways. Trends Neurosci. 7:273-280; 1987.

12. De Boni, U.; Crapper-McLachlan, D. R. Controlled induction of paired helical filaments of the Alzheimer's type in cultured human neurons, by glutamate and aspartate. J. Neurol. Sci. 68:105-118; 1985.

13. Dewar, D.; Chalmers, D. T.; Graham, D. I.; McCulloch, J. Glutamate metabotropic and AMPA binding sites are reduced in Alzheimer's disease:an autoradiographic study of the hippocampus. Brain Res. 553:58-64; 1991.

14. Engelsen, B. Neurotransmitter glutamate: Its clinical importance. Acta Neurol. Scand. 74:337-355; 1986.
15. Felleman, D. J.; Van Essen, D. C. Distributed hierarchical processing in the primate cerebral cortex. Cerebral Cortex 1:1-47; 1991.

16. Fonnum, F. Glutamate: A neurotransmitter in mammalian brain. J. Neurochem. 42:1-11;1984.

17. Foster, A. C. Physiology and pathophysiology of excitatory amino acid neurotransmitter systems in relation to Alzheimer's disease. Adv. in Neurol. 51:97-101; 1990.

18. Fox, K. H.; Sato, H.; Daw, N. The location and function of NMDA receptors in cat and kitten visual cortex. J. Neurosci. 9:2443-2454; 1989.

19. Greenamyre, J. T. The role of glutamate in neurotransmission and in neurologic disease. Arch. Neurol. 43:1058-1063; 1986.

20. Greenamyre, J. T.; Olson, J. M. M.; Penney, J. B.; Young, A. B. Autoradiographic characterization of $\mathrm{N}$-methyl-D-aspartate-, quisqualate- and kainate-sensitive glutamate binding sites. J. Pharmacol. Exp. Ther. 233:254-263; 1985

21. Greenamyre, J. T.; Penney, J. B.; D'Amato, C. J.; Young, A. B. Dementia of the Alzheimer's type: Changes in hippocampal L- $\left[{ }^{3} \mathrm{H}\right]$ glutamate binding. J. Neurochem. 48:543-551; 1987.

22. Greenamyre, J. T.; Penney, J. B.; Young A. B.; D'Amato C. J.; Hicks, S. P.; Shoulson, I. Alterations in L-glutamate binding in Alzheimer's and Huntington's diseases. Science 227:1496-1499; 1985.

23. Greenamyre, J. T.; Young, A. B. Excitatory amino acids and Alzheimer's disease. Neurobiol. Aging 10:593-602; 1989.

24. Greenamyre, J. T.; Young, A. B. Author's response to commentaries. Neurobiol. Aging 10:618-620; 1989.

25. Horton, J. C.; Hedley-Whyte, E. T. Mapping of cytochrome oxidase patches and ocular dominance columns in human visual cortex. Philos. Trans. R. Soc. Lond [Biol.] 304:255-272; 1984

26. Jansen, K. L. R.; Faull, R. L. M.; Dragunow, M. Excitatory amino acid receptors in the human cerebral cortex: a quantitative autoradiographic study comparing the distributions of $\left[{ }^{3} \mathrm{H}\right] \mathrm{TCP},\left[{ }^{3} \mathrm{H}\right] \mathrm{glycine}$, L- $\left[{ }^{3} \mathrm{H}\right]$ glutamate, $\left[{ }^{3} \mathrm{H}\right] \mathrm{AMPA}$ and $\left[{ }^{3} \mathrm{H}\right]$ kainic acid binding sites. Neuroscience 32:587-607; 1989.

27. Jansen, K. L. R.; Faull, R. L. M.; Dragunow, M.; Synek, B. L. Alzheimer's disease: Changes in hippocampal N-methyl-D-aspartate, quisqualate, neurotensin, adenosine, benzodiazepine, serotonin, and opioid receptors-an autoradiographic study. Neuroscience 39:613$127 ; 1990$.

28. Kemper, T. Neuroanatomical and neuropathological changes in normal aging and dementia. In: Albert, M. L., ed. Clinical neurology of aging. New York: Oxford; 1984: 9-52. 
29. Khachaturian, Z. S. Diagnosis of Alzheimer's disease. Arch Neurol 42:1097-1105; 1985.

30. Kisvarday, Z. F.; Cowey, A.; Smith, A. D.; Somogyi, P. Interlaminar and lateral excitatory amino acid connections in the striate cortex of monkey. J. Neurosci. 9:667-682; 1989.

31. Koh J-Y., Yang, L. L.; Cotman, C. W. $\beta$-Amyloid protein increases the vulnerability of cultured cortical neurons to excitotoxic damage. Brain Res. 533:315-320; 1990.

32. Kowall, N. W.; Beal, M. F. Glutamate-, glutaminase-, and taurineimmunoreactive neurons develop neurofibrillary tangles in Alzheimer's disease. Ann. Neurol. 29:162-167; 1991.

33. Kutsuwada, T.; Kashiwabuchi, N.; Mori, H.; Sakimura, K.; Kushiya, E.; Araki, K.; Meguro, H.; Masaki, H.; Kumanishi, T.; Arakawa, M.; Mishina, M. Molecular diversity of the NMDA receptor channel. Nature 358:36-41; 1992.

34. Lewis, D. A.; Campbell, M. J.; Terry, R. D.; Morrison, J. H. Laminar and regional distributions of neurofibrillary tangles and neuritic plaques in Alzheimer's disease: A quantitive study of visual and auditory cortices. J. Neuroscience 7(6):1799-1808; 1987.

35. Lund, J. S. Organization of neurons in the visual cortex, area 17, of the monkey (Macaca mulatta). J. Comp. Neurol. 147:455-496; 1973.

36. Mann, D. M. A.; Yates, P. O.; Marcyniuk, B. A. A comparison of nerve cell loss in cortical and subcortical structures in Alzheimer's disease. J. Neurol. Neurosurg. Psychiatry 43:310-312; 1986.

37. Maragos, W. F.; Chu, D. C. M.; Young, A. B.; D'Amato, C. J.; Penney, J. B. Loss of hippocampal $\left[{ }^{3} \mathrm{H}\right] \mathrm{TCP}$ binding in Alzheimer's disease. Neurosci. Lett. 74:371-376; 1987.

38. Maragos, W. F.; Greenamyre, J. T.; Penney, J. B.; Young, A. B. Glutamate dysfunction in Alzheimer's disease: A hypothesis. Trends Neurosci. 10:65-68; 1987

39. Mattson, M. P. Antigenic changes similar to those seen in neurofibrillary tangles are elicited by glutamate and calcium influx in cultured hippocampal neurons. Neuron 4:105-117; 1990.

40. Mattson, M. P.; Cheng, B.; Davis, D.; Bryant, K.; Lieberburg, Rydel R. E. $\beta$-amyloid peptides destabilize calcium homeostasis and render human cortical neurons vulnerable to excitotoxicity. J. Neurosci. 12: 376-389; 1992.

41. Maunsell, J. H. R.; Van Essen, D. C. The connections of the middle temporal visual area (MT) and their relationship to a cortical hierarchy in the macaque monkey. J. Neurosci. 3:2563-2586; 1983.

42. McCormick, D. A.; Williamson, A. Convergence and divergence of neurotransmitter action in human cerebral cortex. Proc. Natl. Acad. Sci. USA 86:8098-8102; 1989.

43. McDonald, J. W.; Penney, J. B.; Johnston, M. V.; Young, A. B. Characterization and regional distribution of strychnine-insensitive $\left[{ }^{3} \mathrm{H}\right]$ glycine binding sites in rat brain by quantitative receptor autoradiography. Neuroscience 35:653-668; 1990.

44. Monaghan, D. T.; Bridges, R. J.; Cotman, C. W. The excitatory amino acid receptors: Their classes, pharmacology, and distinct properties in the function of the central nervous system. Annu. Rev. Pharmacol. Toxicol. 29:365-402; 1989.

45. Monaghan, D. T.; Olverman, H. J.; Nguyen, L.; Watkins, J. C.; Cotman, C. W. Two classes of N-methyl-D-aspartate recognition sites: Differential distribution and differential regulation by glycine. Proc. Natl. Acad. Sci. USA 85:9836-9840; 1988.

46. Monaghan, D. T.; Yao, D.; Cotman, C. W. Distribution of $\left[{ }^{3} \mathrm{H}\right]$ AMPA binding sites in rat brain as determined by quantitative autoradiography. Brain Res. 324:180-164; 1984.

47. Monyer, H.; Sprengel, R.; Schoepfer, R.; Herb, A.; Higuchi, M.; Lomeli, H.; Burnashev, N.; Sakmann, B.; Seeburg, P. H. Heteromeric NMDA receptors: Molecular and functional distinction of subtypes. Science 256:1217-1221; 1992.

48. Moriyoshi, K.; Masu, M.; Ishii, T.; Shigemoto, R.; Mizuno, N.; Nakanishi, S. Molecular cloning and characterization of the rat NMDA receptor. Nature 354:31-38; 1991

49. Morrison, J. H.; Scherr, S.; Lewis, D. A.; Campbell, M. J.; Bloom, F. E.; Rogers, J.; Benoit, R. The laminar and regional distribution of neocortical somatostatin and neuritic plaques: Implications for $\mathrm{Alz}$ heimer's disease as a global neocortical disconnection syndrome. In: Scheibel, A. B.; Weschler, A. F.; eds. The biological substrates of Alzheimer's disease. New York: Academic; 1986:115-131.
50. Neilsen, E. O.; Cha, J. J.; Honore, T.; Penney, J. B.; Young, A. B Thiocyanate stabilizes AMPA binding to the quisqualate receptor. Eur. J. Pharmacol. 157:197-203; 1988.

51. Olney, J. W. Excitotoxin-mediated neuron death in youth and old age. Prog. Brain Res. 86:37-51; 1990.

52. Pan, H. S.; Frey, K. A.; Young, A. B.; Penney, J. B., Jr. Changes in $\left[{ }^{3} \mathrm{H}\right]$ muscimol binding in substantia nigra, entopeduncular nucleus, globus pallidus, and thalamus after striatal lesions as demonstrated by quantitative receptor autoradiography. J. Neurosci. 3:1189-1198; 1983.

53. Pearson, R. C. A.; Esiri, M. M.; Hiorns, R. W.; Wilcock, G. K.; Powell, T. P. S. Anatomical correlates of the distribution of the pathological changes in the neocortex in Alzheimer disease. Proc. Natl. Acad. Sci. USA 82:4531-4534; 1985.

54. Penney, J. B.; Maragos, W. F.; Greenamyre, J. T.; Debowey, D. L.; Hollingsworth, Z.; Young, A.B. Excitatory amino acid binding sites in the hippocampal region of Alzheimer's disease and other dementias. J. Neurol. Neurosurg. Psychiatry 53:314-320; 1990.

55. Perry, R. H. Recent advances in neuropathology. Br. Med. Bull $42: 34-41 ; 1986$.

56. Procter, A. W.; Palmer, A. M.; Francis, P. T.; Lowe, S. L.; Neary, D.; Murphy, E.; Doshi, R.; Bowen, D. M. Evidence of glutamatergic denervation and possible abnormal metabolism in Alzheimer's disease. J. Neurochem. 50:790-802; 1988.

57. Procter, A. W.; Stirling, J. M.; Stratmann, G. C.; Cross, A. J.; Bowen, D. M. Loss of glycine-dependent radioligand binding to the $\mathrm{N}$-methyl-D-aspartate-phencyclidine receptor complex in patients with Alzheimer's disease. Neurosci. Lett. 101:62-66; 1989.

58. Procter, A. W.; Stratmann, G. C.; Francis, P. T.; Lowe, S. L.; Bertolucci, P. H. F.; Bowen, D. M. Characterisation of the glycine modulatory site of the $\mathrm{N}$-methyl-D-aspartate receptor-ionophore complex in human brain. J. Neurochem. 56:299-310.

59. Procter, A. W.; Wong, E. H. F.; Stratmann, G. C.; Lowe, S. L.; Bowen, D. M. Reduced glycine stimulation of $\left[{ }^{3} \mathrm{H}\right] \mathrm{MK}-801$ binding in Alzheimer's disease. J. Neurochem. 53:698-704; 1989.

60. Rogers, J.; Morrison, J. H. Quantitative morphology and regional and laminar distributions of senile plaques in Alzheimer's disease. J. Neurosci. 5:2801-2808; 1985.

61. Shaw, C.; Cyander, M. Laminar distribution of receptors in monkey (Macaca fascicularis) geniculostriate system. J. Comp. Neurol. 248: 301-312; 1986.

62. Steele, J. E.; Palmer, A. M.; Stratmann, G. C.; Bowen, D. M. The $\mathrm{N}$-methyl-D-aspartate receptor complex in Alzheimer's disease: $\mathrm{Re}-$ duced regulation by glycine but not zinc. Brain Res. 500:369-373; 1989

63. Standaert, D.; Testa, C, Penney, J. B.; Young, A. B. Alternatively spliced isoforms of the NMDAR1 glutamate receptor subunit: Differential expression in the basal ganglia of the rat. Neurosci. Lett.; 1993, in press.

64. Streit, P. Glutamate and aspartate as transmitter candidates for systems of the cerebral cortex. In: Peters, A.; Jones, E. G., eds. Cerebral cortex, vol. 2. New York: Plenum Press; 1984:119-143.

65. Sugihara, H.; Moriyoshi, T.; Ishii, T.; Masu, M.; Nakanishi, S. Structures and properties of seven isoforms of the NMDA receptor generated by alternative splicing. Biochem. Biophys. Res. Commun. 185:826-832; 1992.

66. Terry, R. D.; Katzman, R. Senile dementia of the Alzheimer type: Defining a disease. In: Katzman, R.; Terry, R. D., eds. Neurology of aging. Philadelphia: Davis; 1983:51-84.

67. Terry, R. D.; Peck, A.; Deteresa, R.; Schechter, R.; Horoupian, D. S. Some morphometric aspects of the brain in senile dementia of the Alzheimer type. Ann. Neurol. 10:1168-1170; 1981.

68. Terry, R. D.; Wisniewski, H. M. The ultrastructure of neurofibrillary tangles and senile plaques. In: Wolstenholme, G. E. W.; O'Connor, M., eds. Alzheimer's disease and related conditions. London:Churchill; 1970:145-165

69. Tsumoto, T. Excitatory amino acid transmitters and their receptors in neural circuits of the cerebral cortex. Neurosci. Res. 9:79-102; 1990.

70. Van Essen, D. C. Functional organization of primate visual cortex. In: Peters, A., Jones, E. G., eds. Cerebral cortex, vol. 3. New York: Plenum; 1985:259-330. 
71. Van Essen, D. C.; Maunsell, J. H. R. Hierarchical organization and functional streams in the visual cortex. Trends Neurosci, 6:370-375: 1983.

72. Vogt, B. A.; Crino, P. B.; Volicer, L. Laminar alterations in $\gamma$-aminobutyric acid $A$, muscarinic, and $\beta$ adrenoceptors and neuron degeneration in cingulate cortex in Alzheimer's disease. J. Neurochem. 57:282-290; 1991 .

73. Walker, F. O.; Young, A. B.; Penney, J. B.; Dorovini-Zis, K.;
Shoulson, I. Benzodiazepine receptors in early Huntington's disease Neurology 34;1237-1240; 1984.

74. Young, A. B.; Fagg, G. E. Excitatory amino acid receptors in the brain: Membrane binding and receptor autoradiographic approaches. TIPS 11:126-133; 1990.

75. Young, W. S.; Kuhar, M. J. Autoradiographic localization of benzodiazepine receptors in the brains of humans and animals. Nature (Lond.) 280:393-395; 1979. 